\title{
The Contribution of Sundanese Expressions and Proverbs as Local Wisdom to Strengthen the National Identity in Facing the Industrial Era 4.0
}

\author{
Sunarni ${ }^{1}$, Hamidah $^{2}$ \\ \{nani.sunarni@unpad.ac.id ${ }^{1}$,idah.hamidah@unsoed.ac.id² \\ ${ }^{1}$ Faculty of Humanities, Padjadjaran University, Bandung, Indonesia \\ ${ }^{2}$ Jenderal Soedirman University, Purwokerto, Indonesia
}

\begin{abstract}
Industrial revolution greatly influences the development of culture, economy, and politics throughout the world. Since the invention of steam engine, mechanization, computerization, robotization, and up to now the industrial era 4.0 have resulted in positive impacts to this millenial era. However, many negative impacts have also arised, especially related to the issues on humanity. Indonesian people who are well acknowledged with their mutual cooperation and cultures, have gradually decreased and resulted in moral degradation that the values of humanity have also been fading out. Thus, an education of humanity sciences based on local wisdom is greatly required. A better understanding on local wisdom from generation to generation may strengthen and provide various contributions for the development of the nation resulting in excellent Indonesian people along with their strong characteristics. This study mainly focuses on Sundanese expressions and proverbs. The data were analyzed through a cultural intelligence approach. This research may theoritically become a reference for a character building development; and practically may be utilized as a teaching material for a cultural study as one process of passing down the local wisdom in facing the industrial era 4.0.
\end{abstract}

Keywords: industrial era 4.0, national identity, local wisdom, Sundanese, proverb, expression

\section{Introduction}

The recently arising digital technology and internet encourages the development of electronic-based industries and information technology. Long before their present existance, a steam engine was first discovered followed by the mechanization and computerization era. The technology discovery may facilitate, simplify, and develop the other sciences and even find new innovations. In fact, when everything may be automatically run, the human power may be replaced that the human employment may even be reduced. In other words, the arising digital and internet technology in this millennium may significantly influence the development of culture, economy, and politics throughout the world. 
However, on the other hand, the development of technology may also significantly influence the cultural changes in which originally based on human shifting based on machine or computer that direct contacts are less frequently made among humans. For example in the world of commerce, transactions between producers and consumers may occur without a face to face meeting. In addition, in educational processes which are based on e-learning, the learners may deepen their knowledge without having face to face meetings with their teachers/lecturers and it is not limited by time and space. Besides those two examples, human contacts are also no longer necessary in many other fields.

Changes in attitudes, behaviors, and thoughts in this era may also change the humans' mindsets, patterns, and conducts. Less direct contacts with others may indirectly and gradually decrease the interpersonal communication. In fact, many millenial generations recently do not like group activities that individualism and egoism are unavoidable. In other words, the term "humanizing the humans" significantly dereases. Due to the existence of information technology, information from outside which is not in accordance with the Indonesian life bases and concepts rapidly infiltrate the nation gradually resulting in losing the Indonesian identity.

The negative impacts may be equalized through the humans' attitudes or behaviors in response to the social changes. Therefore, one fundamental basis to prevent from those negative impacts is by implementing the local wisdom. Indonesia is a country with cultural intelligence values contained in its expressions or proverbs. The Indonesian Great Dictionary (1988:755) mentions that proverb is brief and meaningful expressions or sentences containing comparisons, parables, advice, life principles, or rules of humans' conducts. Based on the above definitions, the proverbs or expressions in Sundanese may be implemented as life principles as well as basic thinking and action patterns in industrial era 4.0. This research will describe the implementation of proverbs or expressions used as the life bases or principles in this industrial era 4.0.

This research employs a descriptive-qualitative method. The research mechanism is based on the research framework. First, identifying the cultural intelligence characteristics which express life behavior attitudes in accordance with the Sundanese people's cultural life philosophy reflected in its expressions and proverbs. The philosophy is then used as a basis for attitudes and behaviors in an effort to equalize the negative impacts resulted from the industrial revolution known as industrial era 4.0.

\section{Result And Discussion}

Indonesian people have recently lived in globalization or modernization era. Based on the Indonesian Great Dictionary (1988: 662), modernization is the shifting processes of attitudes and mentalities as the citizens to live in accordance with the present demands. Modernization, in social sciences, refers to the forms of transformation starting from a less developed state to a better one in in accordance with people's hopes to live better. In Indonesia, modernization covers all life sectors, including transportation, communication, agriculture, manufacturing and others. Among those sectors, the most dominant or prominent one is communication technology. Based on the data obtained from UNESCO, 4 of 10 Indonesian people are active on social media, such as Facebook with 3.3 million users, then 
WhatsApp with 2.9 million users and others. Meanwhile, the data obtained from Social Media Analytics Tools per January 31, 2019, the active social media users in Indonesia have reached 150 million users from the total Indonesian population of 268.2 million or $56 \%$.

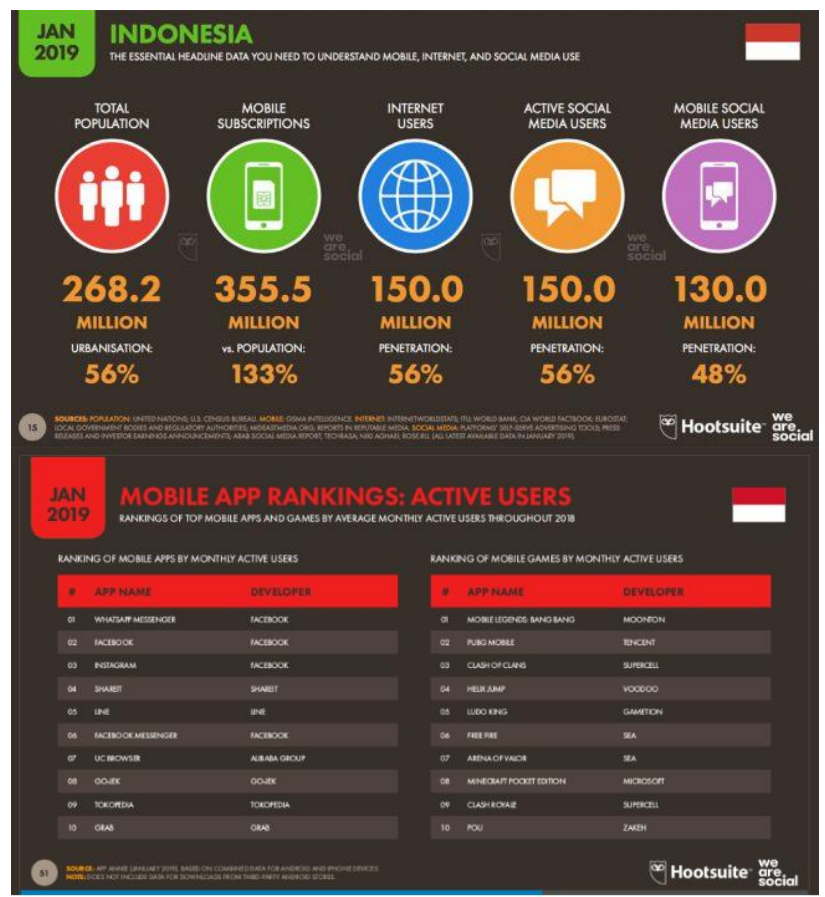

The use of this rapidly growing social media has positive and negative impacts on people's social life. Moreover, based on the data above, the Indonesian people are highly active in utilizing the social media.

Communication technology has positive impacts for Indonesian people, especially related to obtaining information both from home and overseas countries. However, Indonesian people should have the capacity to filter information which is in accordance with the values of Indonesian people. Based on the empirical data, many Indonesian people including those underage children and even toddlers have been given gadgets without supervision. In fact, they have not been able to distinguish whether or not it is appropriate and in accordance with the values upholded by this nation. This is one factor causing a moral degradation.

As one effort to provide foundation and anticipation to those which are undesirable, Sundanese people have proverbs and expressions used as their life guidance in this industrial era 4.0 and even for the future as the basis for character building to strengthen their selfidentity. Proverb is one cultural element originated and developed from the communities generally used as their life guidance. Proverbs are created by certain communities based on experiences and factual events. Proverbs are the civilization reflection and symbol of people's identity. Proverbs appear with didactic purposes for the communities in their era and their values are applicable even until today and to the future.

Every nation in the world has proverbs reflecting the nation's character and identity. Similarly, Sundanese proverbs have their own characteristics describing its customs and 
traditions. One Sundanese proverb "moal linduh kaiuhan moal gedag kaanginan" means panceg pamadegan (strong ideology). So the proverb means 'not easily affected'.

Indonesian people who live in this globalization or modern era should be able to wisely sort and select the information coming to Indonesia both from home and overseas countries. Therefore, the values specifically contained in expressions or proverbs must be inherited through education starting from home or family level education in the society or schools.

Sundanese local wisdom values are not only contained in its proverbs but also in its expressions as their life concepts as shown in the unity of the value "cageur" which means 'healthy', "bageur" which means good behavior, "bener"which means right/correct, 'pinter' which means "smart", "jujur" which means honest, "akur" which means 'friendly', "singer" which means "creative", and "wanter" which means dare to perform directed to achieve a compassionate civilian who is "pengkuh agamana", 'strong in religion', jembar budayana 'rich in culture', luhung elmuna 'high in knowledge', and rancage gancena 'creative'. Due to the implementation of the intended values, cultural intelligence has become an important aspect to be empowered as the thinking and acting foundation in this industrial era 4.0. The concept of "cageur" is not only physically but also emotionally and mentally healthy. If you are physically, emotionally, and mentally healthy, you will be good, right, honest, smart, creative, and friendly in every action.

If all values become the identity of each Indonesian citizen, they must be able to show their existence and cultural intelligence characteristics. Fadlillah (2006: 47) states that the characteristics of people who have cultural intelligence must have goof life attitudes, such as hard working, workaholic, resutling the best when working, having short and long term life planning, appreciating time, having the attitude that today is much better than yesterday, responsible, honest and having integrity, good at saving and making investment, respecting social rules and laws. The implementation of local wisdom values as the foundation to face this industrial era 4.0 is as follows:

\begin{tabular}{|c|c|}
\hline Cageur 'healthy' & $\begin{array}{l}\text { Logical to both positive and negative values in response to the } \\
\text { development of technology in the industrial era } 4.0 \text {. }\end{array}$ \\
\hline Bageur 'good' & $\begin{array}{l}\text { Able to accept the positive values in response to the development of } \\
\text { technology in the industrial era } 4.0 \text {. }\end{array}$ \\
\hline Bener 'right' & $\begin{array}{l}\text { Correctly using the positive values in response to the development of } \\
\text { technology in the industrial era } 4.0 \text {. }\end{array}$ \\
\hline Pinter 'smart' & $\begin{array}{l}\text { Smartly understanding and using the positive values in response to the } \\
\text { development of technology in the industrial era } 4.0 \text {. }\end{array}$ \\
\hline Jujur 'honest' & $:$ \\
\hline Akur 'friendly' & $\begin{array}{l}\text { Honestly understanding the positive values in response to the } \\
\text { development of technology in the industrial era 4.0. }\end{array}$ \\
\hline \multirow[t]{3}{*}{ Singer 'creative' } & ( \\
\hline & $\begin{array}{l}\text { Able to accept the positive values and wisely rejecting the negative ones } \\
\text { in response to the development of technology in the industrial era 4.0. }\end{array}$ \\
\hline & $\begin{array}{l}\text { Creative in utilizing positive values in response to the development of } \\
\text { technology in the industrial era } 4.0 \text {. }\end{array}$ \\
\hline Wanter 'dare' & $\begin{array}{l}\text { Dare and able to use the positive values in response to the development of } \\
\text { technology in the industrial era 4.0. }\end{array}$ \\
\hline
\end{tabular}


The relationship between the cultural intelligence and implementation of the above local wisdom values are elaborated through three dimensions: knowledge, motivation, and behavior. The knowledge dimension is measured through the value of cageur and pinter. The motivation dimension is measured through the values of bageur and wanter. Meanwhile, the behavior dimension is measured through jujur, akur, bener, singer, and wanter. Those values are described and visualized as follows.

\section{Cultural Intelligence in Industrial era Era 4.0}
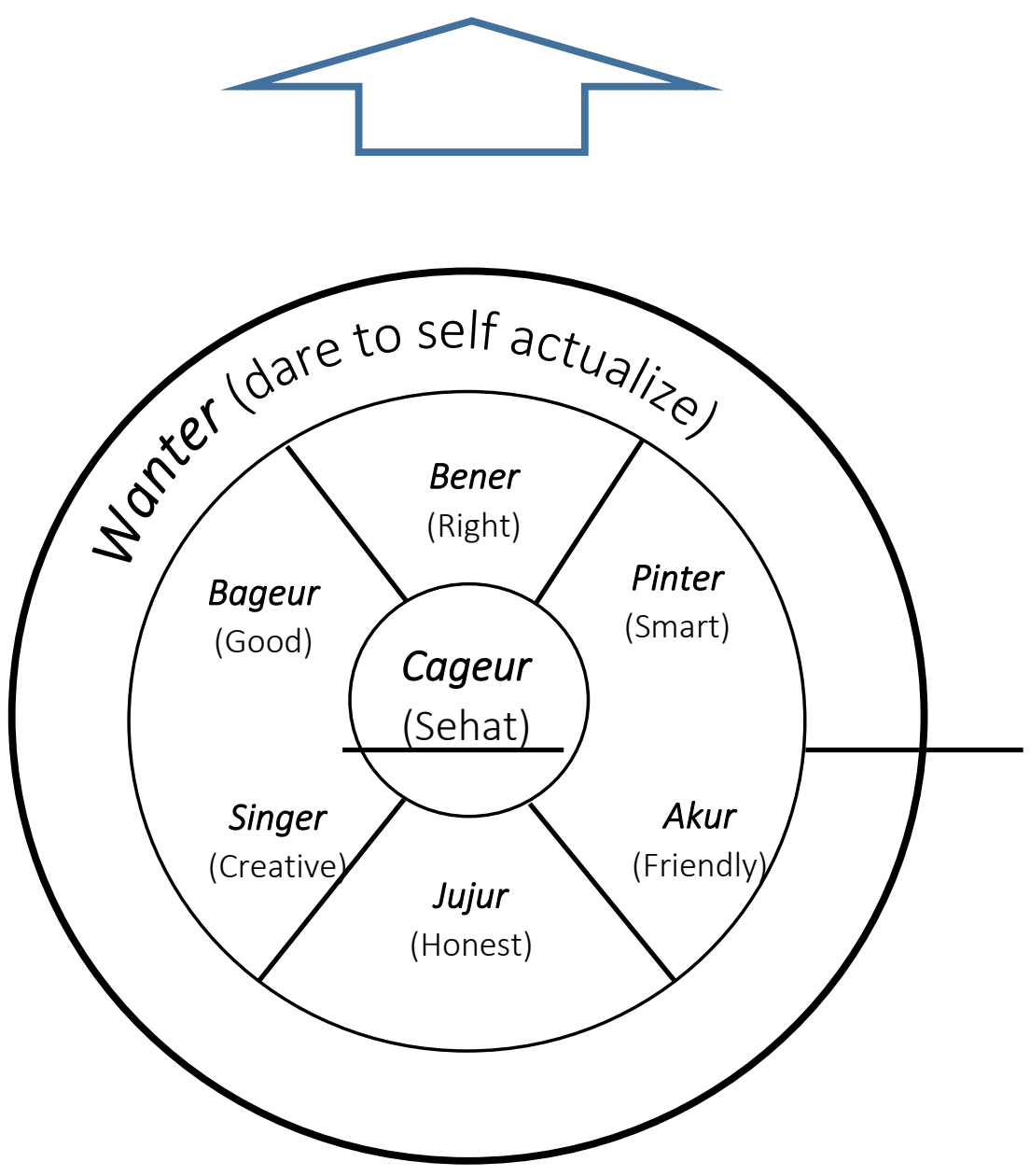


\section{Conclusion}

Technology gradually develops. It rapidly develops in the developed countries, yet slowly in developing countries, such as Indonesia. The most dominant technology in Indonesia is information technology. The existence of digital technology and internet makes everyone easily obtain information both from home and overseas countries. Information is not always in accordance with the cultures and values which become the Indonesian people's philosophical foundation. However, Indonesian people may eventully lose their identity. Therefore, the noble values contained in proverbs and expressions as a part of the culture in forming the character of the nation may be used as a foundation and implemented to face the industrial era 4.0 and even to the coming eras.

\section{References}

[1] Badudu, J.S. 1988. Kamus Besar Bahasa Indonesia. Jakarta: Balai Pustaka.

[2] Fadlillah. 2006. Kecerdasan Budaya. Padang: Andalas Unversity Press.

[3] Nugraha. 2008. Ngamumule Basa Sunda. Bandung: Yrama Widya.

[4] Sunarni, Nani dkk. 2013. Kajian Implementasi Nilai-Nilai Kearifan Lokal Budaya Sunda

[5] dalam Kurikulum dan Media Pembelajaran. Bandung: CV Semiotika.

[6] Website. https://hootsuite.com/id. (C) 2019 Hootsuite Inc. 